Victor KOZHUKHAR'

\title{
HISTORIOGRAPHY AND EMPIRICAL BASE OF ETHNODEMOGRAPHIC STUDIES OF UKRAINIANS IN THE REPUBLIC OF MOLDOVA AT THE END OF THE XX - BEGINNING OF THE XXI CENTURY \\ https://doi.org/10.52603/rec.2021.29.04
}

\begin{abstract}
Rezumat
Istoriografie și baza empirică a studiilor etnodemografice ale ucrainenilor din Republica

Moldova la sfîrșitul XX - începutul secolului XXI

În acest articol sunt examinate cercetările privind demografia din Republica Moldova la sfârșitul secolului XX - începutul secolului XXI. Se remarcă faptul că după 1991, atenția strânsă a cercetătorilor, a jurnaliștilor, a organizațiilor publice este îndreptată către problemele demografiei. Autorii urmăresc dinamica proceselor demografice din Moldova, determină cauzele și posibilele consecințe ale proceselor negative, oferă soluții pentru îmbunătățirea situației. În mod convențional, putem împărți toate publicațiile în trei secțiuni: 1) lucrări care iau în considerare situația demografică şi dinamica acesteia în țară în ansamblu; 2) lucrările care studiază problemele de migrație; 3) lucrări în domeniul de etnodemografie, adică lucrări dedicate proceselor demografice din mediul comunităților etnice. Cu toate acestea, până când nu există multe studii etnodemografice speciale asupra ucrainenilor în Moldova. În articol sunt discutate, de asemenea, principalele surse de cercetare etnodemografică: recensămintele populației, contabilitatea curentă a evenimentelor demografice, sondaje speciale, liste și registre ale populației. $\mathrm{O}$ analiză a fiecărui grup de surse este dată din punctul de vedere al informativității acestora pentru un studiu etno-demografic deplin al ucrainenilor din Moldova.
\end{abstract}

Cuvinte-cheie: Republica Moldova, etnodemografie, ucraineni, istoriografie, bază empirică.

\section{Резюме}

Историография и эмпирическая база этнодемографических исследований украинцев Республики Молдова в конце XX - начале XXI в.

В статье рассматриваются исследования по демографии в Республике Молдова в конце XX - начале XXI в. Отмечается, что после 1991 г. к проблемам демографии приковано пристальное внимание исследователей, журналистов, общественных организаций. В многочисленных работах авторы прослеживают динамику демографических процессов в Молдове, определяют причины и возможные последствия негативных процессов, предлагают варианты решений для улучшения ситуации. Условно мы можем разделить все публикации на три категории: 1) работы, в которых рассматривается демографическая ситуация и ее динамика по стране в целом; 2) работы по проблемам миграции; 3) работы по этнодемографии, то есть посвященные демографическим процессам в среде этнических сообществ. Однако специальных этнодемографических исследований по украинцам Молдовы пока не много. В статье также рассматриваются основные источники для этнодемографических исследований: переписи населения, текущий учет демографических событий, специальные выборочные обследования, списки и реестры населения. Дается анализ каждой группы источников с точки зрения их информативности для полноценного этнодемографического исследования украинцев Молдовы.

Ключевые слова: Республика Молдова, этнодемография, украинцы, историография, эмпирическая база.

\section{Summary \\ Historiography and empirical base of ethnodemographic studies of Ukrainians in the Republic of Moldova at the end of the XX - beginning of the XXI century}

The article presents studies on demography in the Republic of Moldova in the late XX - early XXI century. It is noted that after 1991 the close attention of researchers, journalists, public organizations is focused on the problems of demography. The authors trace the dynamics of demographic processes in Moldova, determine the causes and possible consequences of negative processes, offer solutions to improve the situation. Conventionally, we can divide all publications into three categories: 1) works that consider the demographic situation and its dynamics in the country as a whole; 2) work on migration issues; 3) works on ethnodemography, i.e. dedicated to demographic processes in the environment of ethnic communities. However, there are not many special ethno-demographic studies on Ukrainians in Moldova. The article also discusses the main sources for ethnodemographic research: population censuses, current accounting of demographic events, special sample surveys, lists and registers of the population. An analysis of each group of sources is given from the point of view of their informativeness for a full-fledged ethno-demographic study of Ukrainians in Moldova.

Key words: Republic of Moldova, ethnodemography, Ukrainians, historiography, empirical base.

\section{Historiography}

After Moldova gained independence in $1991^{1}$, the problems of demography have attracted close attention of researchers, journalists, and public organizations. This is due to the turbulence that is observed in the demographic situation. We can conditionally divide all publications into three categories:

1) works that consider the demographic situation and its dynamics in the country as a whole (Дудогло, Онофрей 2013; Большакова, Черкасов 2019; Фоменко, Кривенко 2002; Гагауз, Пенина 2010; Гагауз 2010: 87-99; Палади, Бучучану-Врабие 
2010; Надирова, Корнелюк, Гагауз 2017: 24-31; Тульский 2006; Гагауз 2019; Paladi, Gagauz, Penina 2009, etc.);

2) works on migration issues (Мошняга 2007, 2008, 2009; Malinovska, Mosneaga, Shahotko 2007; Mosneaga, Rusu 2008; Джуда 2020; Молдавские... 2012; Поалелунжь 2010; Макухин 2015, etc.);

3) works on ethnodemography, i.e. devoted to demographic processes in the environment of ethnic communities (Табак 1990; Скворцова 2002; Субботина 2005; Дарадур 2009; Суляк 2013; Кожухарь 2017, 2020 (a), 2020 (b), etc.).

The headings of the articles themselves speak eloquently about the general leitmotif of works on demography ("Moldova in the process of depopulation", "Moldova needs urgent measures to preserve human potential", "Aging of the population in the Republic of Moldova, a regional aspect", etc.). And this is not a panic, this is an understanding of the catastrophic nature of the situation, which the authors seek to convey to the authorities. And the situation is really not simple: the birth rate is decreasing, the mortality rate is increasing (the number of deaths since 1995 exceeds the number of births), the number of people leaving the country in search of a better life is increasing (first for temporary work, now - with their families and forever), the structure of the population, the proportion of citizens over 60 is growing, life expectancy is significantly reduced, etc.

Let's turn to the numbers. From 1959 to 1989 , the population in the republic grew steadily from 2.9 million to 4.3 million. And since the beginning of the 1990s is constantly falling, and at the moment it is 2.6 million people. Thus, over 30 years we have decreased by 1 million 700 thousand, or $40 \%$.

From 1970 to 1990, the average population growth in the republic was $47.3 \%$ per year. And since the beginning of the 1990s, we have seen the opposite trend - the population decline averages $13 \%$ annually (Anuarul 2002-2020).

In the above-mentioned works, the authors trace the dynamics of demographic processes in Moldova, determine the causes and possible consequences of negative processes, offer solutions to improve the situation.

In our vision, indicative is the opinion of a foreign author - the columnist for the Economist magazine Tim Judah. Having familiarized himself with the demographic situation in our country, he was so stunned that he wrote a solid article in his publication "Balkan Insight: Will Population Migration Kill Moldova?", In which he refers to the data of Moldovan sociologists and demographers. He begins the article with the words: "If for the countries located between the Black Sea and the Adriatic, the problem of population de- cline is a drama, then in Moldova it is a tragedy. Since 1989, the country's population has declined by almost a third; in 15 years only half of it may remain". And he ends with the opinion of sociologist Vadim Pistrinchuk: "...unless radical changes take place in Moldova, including a complete «restoration of governance» (which means a break with the corrupt and oligarchic practices of the past), then the country is doomed to become a «Holiday House» for those who left, and a «nursing home» for those who stayed" (Judah 2020). The answer to the question posed in the title of the article is obvious.

Most experts agree that migration is the main factor in depopulation, although a decrease in the birth rate and an increase in mortality also make a significant contribution.

Domestic demographers believe that such a noticeable decrease in the birth rate in Moldova since the beginning of the 90s occurred for two main reasons:

- the number of women of the most childbearing age has decreased - this is the third wave of the demographic consequences of the Second World War;

- over two thirds of families now refuse to have children for material reasons (Георгиева 2020: 140).

However, depopulation was determined not so much by the low birth rate as by the high mortality rate of the population. The mortality statistics of the population in Moldova for the studied period of time shows a moderate tendency of its growth with the growth rate of 11.4\% (Бобкова 2009: 3-7).

The most significant influence on the formation of mortality trends is exerted by socio-economic factors, such as the impact of working and living conditions, work and rest regimes, housing conditions, the quality of drinking water and food, the degree of development and availability of qualified medical care, the social security system, social infrastructure and the service sector, material well-being, etc. The works of domestic authors noted a significant impact on health and life expectancy, poverty, social disintegration, crime and psychosocial factors (Большакова, Черкасов 2019: 37; Горбунова, Ецко 2017: 33; Фоменко 2009: 84).

Since nuptiality also affects the population (albeit indirectly), a number of specialists pay attention to it. Thus, O. Gagauz examines the dynamics of nuptiality in the late XX - early XXI centuries (changes in the level and structure of nuptiality based on data from the 1989 and 2004 population censuses). The author did a great job structuring the statistics and compiling tables, charts and graphs that were carefully analyzed. In conclusion, it is noted that "the marriage rate of the population of the Republic of Moldova corresponds to the modern type, characteristic of most European countries. The intensity of marriage is decreasing, while its calendar is shifting (the age of marriage is 
increasing), the level of celibacy is increasing, and unregistered marriages are becoming more common. The transformation of nuptiality is largely due to the changes that have taken place in the socio-economic and cultural development of society, in the system of life priorities, as well as the penetration of Western values, individualization of private life, which contributes to the «erosion» of the standards of marriage and family relations" (Гагауз 2010: 99).

Several works have been published on the demography of ethnic groups in Moldova, which are quite interesting and useful for researchers.

In 1990 the monograph by I. V. Tabak "The Russian population of Moldova. Number, settlement, interethnic ties", which studies the features of settlement and dynamics of the Russian population in Moldova since the second half of the 19th century until the 80s XX century was published (Табак 1990).

In the monograph by A. Yu. Skvortsova, devoted to the study of the situation of the Russians of Moldova in the interwar period, we also find statistical data on the dynamics of the number, the structure of the population, etc. (Скворцова 2002).

Several works have been written on the Gagauz theme (Субботина 2005: 115-133; Дарадур 2009, etc.). Researchers examine the historical roots of the current problems in demography, reveal their causes, taking into account the ethnic specificity of the Gagauz population of Moldova.

As for the Ukrainians, there are still few special works on demography. Works on migration processes, historiography and source study of demographic processes among Ukrainians in Moldova have been published (Кожухарь 2017, 2020a, 2020b). Certain information on the number and settlement is contained in works on the long and modern history of local Ukrainians (Кожухар 2008; Степанов 2007, etc.).

Well, to study the natural and mechanical movement of the Ukrainian population, it is necessary to determine the distinctive features of the demographic attitude of this ethnic group, the reasons for its transformations in the context of modern demographic trends and their consequences for the socio-economic stability of society. Therefore, research on ethnology, primarily ethnic psychology, national traditional culture (family traditions, folk medicine, folk pedagogy, etc.) is also important here. Such knowledge will help to identify the causes of some demographic processes among Ukrainians in Moldova.

And since there are very few special ethno-demographic studies on Ukrainians in Moldova, and the indicated aspects of traditional culture have not been sufficiently studied, such scientific research becomes very relevant.

\section{Sources}

The study of demographic processes and phenomena, the identification of their trends and patterns, as well as the implementation of various practical developments (forecasts, programs) require the use of significant amounts of information about the population.

The specificity of the population lies in the fact that the way of its existence and self-preservation is constant variability, fluidity, transition from one state to another. The characteristics of the population as a whole as a set of people change over a certain period of time as a result of demographic events (birth, death, marriage (dissolution), migration) occurring with an individual at a particular moment.

This necessitates the use of an appropriate system for recording and collecting demographic data. The existing practice distinguishes between "accounting for the state of the population at a certain point in time and accounting for demographic events (births, deaths, marriages, divorces, as well as moving from place to place) for a particular period of time" (Медков 2002: 15).

In the first case, the sources of demographic data are population censuses and special sample, including sociological, surveys carried out by research, project, and public organizations. In the second, data on the registration of demographic events are used, in particular, records in registers of births, acts of civil status.

Population data can also be obtained from electoral, military registration and other lists. Population registers, which combine the properties of censuses and current population records, are also ranked as sources of demographic information.

Thus, the main sources of primary demographic data are: population censuses, current records of demographic events, special sample surveys, lists and registers of the population.

The most complete and comprehensive source of demographic information is population censuses.

We propose to carry out a comparative analysis of demographic information obtained from the materials of the population censuses of 1959, 1979, 1989 and 2004 (we will not take into account the results of the "census" of 2014, see: Кожухарь 2020a: 295-299.)

Let's dwell on the last of them (2004). The most important thing for us is information about the ethnic composition of the population. Here we find data on the total number of the Ukrainian population 282406 people (their share has significantly decreased compared to the previous census), their distribution by area (urban and rural), the native language of Ukrainians (among Ukrainians, 64.1\% named Ukrainian as their native language, and $31.8 \%$ - Russian), the language in which they usually speak (every second 
Ukrainian usually speaks their native language, and 6.2\% - in Russian), etc. (Перепись 2006: 52-58).

It is also important for us that the ethnic composition of the population is represented by district and separately for each locality. Based on this information, we have identified three groups of settlements, where:

1) Ukrainians make up less than $30 \%$ of the population;

2) from 30 to $50 \%$;

3) over $50 \%$.

This allows us to specifically determine the regions of compact and dispersed settlement of Ukrainians, the number of Ukrainians living in urban and rural areas, etc.

It is also possible, in the territorial context, to trace the ratio of the number of Ukrainians who have determined Ukrainian as their native language, and what language they usually speak.

However, the reliability of the data in this statistical source raises serious doubts among a number of scientists (Суляк 2013: 96; Тишков 2011, etc.).

But, nevertheless, this is so far the only official document on the population census in the Republic of Moldova since independence, and we have to use it.

The main additional sources include data from the "Center for State Information Resources «Registru» (ÎS „CRIS «Registru»”); annual statistical compilations of the National Bureau of Statistics (however, data on ethnicity are almost not provided, but it is possible to indirectly calculate data on Ukrainians); military credentials, etc.

A fairly serious comparative analysis of the 2004 census data and the data of the "Center for State Information Resources «Registru» (ÎS „CRIS «Registru») was carried out by S. G. Sulyak. When it comes to specifying ethnicity and other parameters, he prefers to rely more on the data of the CRIS „Registru” (information on nationality and mother tongue is declared and rechecked by citizens themselves when filling out forms for issuing an identity card or a foreign passport), thereby calling into question the reliability of the 2004 census data (Суляк 2013).

Considering that our study deals specifically with ethnic demography, we should single out such an important source of information as materials of ethnographic research, primarily field materials that we have been collecting for 30 years. They will make it possible to identify the causes of some demographic processes, based on the characteristics of the national traditional culture (family traditions, folk medicine, folk pedagogy, etc.).

Thus, the existing sources allow us to give a definite picture of the ethno-demographic processes among the Ukrainians in Moldova, and, first of all, the dynamics of the population movement.
And, considering that the Ukrainian population in almost the entire history of its existence on the lands of Moldova was not the object of special demographic studies, but was mentioned, as a rule, only in the context (among others), fragmentarily and this data was not subjected to serious scientific analysis, we believe that our scientific searches are quite relevant, including for creating a general picture of the demographic state and development of our society. This, in turn, will make it possible to make forecasts and give specific recommendations for the authorities to stabilize and achieve positive dynamics of demographic processes in our country.

\section{Note}

${ }^{1}$ The analysis of studies on demography and ethnodemography in Moldova in the 19th - 20th centuries is presented in our other article (Кожухарь 2020 (b)).

\section{References}

Anuarul statistic al Republicii Moldova. Chișinău: Statistica, 2002-2020.

Mosneaga V., Rusu R. Formarea diasporei moldovenești peste hotare: esența și specificul. În: Moldoscopie (Probleme de analiza politică), nr. 1 (XL), 2008. Chișinău: USM, 2008, p. 91-104.

Malinovska O., Mosneaga V., Shahotko L. Labour Migration Assessment for the WNIS Region. Kiev: IOM, October 2007. 60 p.

Paladi G., Gagauz O., Penina O. Îmbătrînirea populaţiei în Republica Moldova: consecinţe economice şi sociale. Chişinău: Inst. Integrare Europeană şi Ştiinţe Politice, 2009. 204 p.

Recensămîntul populaţiei $=$ Перепись населения = Population census, 2004: Culeg. statistică: [În 4 vol.] / Biroul Naţional de Statistică al Republicii Moldova. Chișinău: Statistica, 2006. 492 p.

Бобкова Е. Социальное и экономическое самочувствие населения двух берегов Днестра в условиях замороженного конфликта. In: Материалы международной научно-практической конференции «Молдова-Приднестровье: общими усилиями - к успешному будущему. Социальные аспекты». Кишинев: $\mathrm{Cu}$ drag, 2009, с. 9-19. / Bobkova E. Social'noe i jekonomicheskoe samochuvstvie naselenija dvuh beregov Dnestra v uslovijah zamorozhennogo konflikta. In: Materialy mezhdunarodnoj nauchno-prakticheskoj konferencii «Moldova-Pridnestrov'e: obshhimi usilijami - k uspeshnomu budushhemu. Social'nye aspekty». Kishinev: $\mathrm{Cu}$ drag, 2009, s. 9-19.

Большакова П. Н., Черкасов С. Н. Анализ особенностей демографических процессов в Молдове и Приднестровье. In: Проблемы стандартизации в здравоохранении. М.: Медико-тех- 
нологическое предприятие «Ньюдиамед», 2019 , № 1-2, с. 34-39. / Bol'shakova P. N., Cherkasov S. N. Analiz osobennostej demograficheskih processov $\mathrm{v}$ Moldove i Pridnestrov'e. In: Problemy standartizacii v zdravoohranenii. M.: Mediko-tehnologicheskoe predprijatie "N'judiamed", 2019, № 1-2, s. 34-39.

Гагауз О. Е., Пенина О. А. Демографические перспективы Молдовы. In: Основные вызовы демографической безопасности: сходства и различия в Молдове и Беларуси. Кишинев: Știința, 2010. http://www.demoscope.ru/weekly/2011/0455/analit01.php. (vizited 20.03.2020). / Gagauz O. E., Penina O. A. Demograficheskie perspektivy Moldovy. In: Osnovnye vyzovy demograficheskoj bezopasnosti: shodstva i razlichija v Moldove i Belarusi. Kishinev: Știința, 2010. http://www.demoscope.ru/weekly/ 2011/0455/analit01.php. (vizited 20.03.2020).

Гагауз О. В Молдове нужны срочные меры по сохранению человеческого потенциала. In: https:// news.myseldon.com/ru/news/index/213638346, 2019 (vizited 13.03.2020). / Gagauz O. V Moldove nuzhny srochnye mery po sohraneniju chelovecheskogo potenciala. In: https://news.myseldon.com/ru/news/index/213638346, 2019 (vizited 13.03.2020).

Гагауз О. Е. Динамика брачности населения Республики Молдова в конце XX - начале XXI века. In: Проблемы народонаселения в зеркале истории: Шестые Валентеевские чтения: М., 22-24 апреля 2010 г. МГУ им. М. В. Ломоносова: Сборник докладов. Т. 2 / Ред. В. В. Елизаров, И. А. Троицкая. М.: МАКС Пресс, 2010, с. 8799. / Gagauz O. E. Dinamika brachnosti naselenija Respubliki Moldova v konce XX - nachale XXI veka. In: Problemy narodonaselenija v zerkale istorii: Shestye Valenteevskie chtenija: M., 22-24 aprelja 2010 g. MGU im. M. V. Lomonosova: Sbornik dokladov. T. 2 / Red. V. V. Elizarov, I. A. Troickaja. M.: MAKS Press, 2010, s. 87-99.

Георгиева Е. Тенденции и динамика демографических процессов в Республике Молдова. In: Международный конкурс студенческих научно-исследовательских работ по экономике. Vol. IV, 1 martie - 30 iunie 2020, Comrat. Comrat: Научно-исследовательский Центр «Прогресс» при Комратском государственном университете, 2020, с. 139-145. / Georgieva E. Tendencii i dinamika demograficheskih processov v Respublike Moldova. In: Mezhdunarodnyj konkurs studencheskih nauchnoissledovatel'skih rabot po jekonomike. Vol. IV, 1 martie - 30 iunie 2020, Comrat. Comrat: Nauchnoissledovatel'skij Centr «Progress» pri Komratskom gosudarstvennom universitete, 2020, s. 139-145.

Горбунова Г. Д., Ецко К. П. Влияние трудовой миграции родителей на состояние здоровья детей Молдовы. In: Бюллетень Национального научно-исследовательского института общественного здоровья имени Н. А. Семашко. М., 2017, № 1, c. 30-35. / Gorbunova G. D., Ecko K. P. Vlijanie trudovoj migracii roditelej na sostojanie zdorov'ja detej Moldovy. In: Bjulleten' Nacional'nogo nauchno-issledovatel'skogo instituta obshhestvennogo zdorov'ja imeni N. A. Semashko. M., 2017, № 1, s. 30-35.

Дарадур Н. Ретроспектива и эволюция семьи и рождаемости у гагаузов Молдовы XIX - начала XXI вв. в контексте демографических тенденций современности. Автореф... дисс. ... докт. истории. Кишинев, 2009. 26 с. / Daradur N. Retrospektiva i jevoljucija sem'i i rozhdaemosti u gagauzov Moldovy XIX - nachala XXI vv. v kontekste demograficheskih tendencij sovremennosti. Avtoref... diss. ... dokt. istorii. Kishinev, 2009. 26 s.

Джуда T. Balkan Insight: миграция населения убьет Молдавию. In: https://rossaprimavera-ru. turbopages.org/s/rossaprimavera.ru/article/053551fc, 2020 (vizited 15.03.2020). / Judah T. Balkan Insight: migracija naselenija ub'et Moldaviju. In: https://rossaprimavera-ru.turbopages.org/s/rossaprimavera.ru/ article/053551fc, 2020 (vizited 15.03.2020).

Дорошенко Л. С. Демографія: Навч. посіб. для студ. вищ. навч. закл. Київ: МАУП, 2005. 112 с. / Doroshenko L. S. Demografija: Navch. posib. dlja stud. vishh. navch. zakl. Kï̈: MAUP, 2005. 112 s.

Дудогло Т. Д., Онофрей А. 3. Оценка демографической нестабильности в Республике Молдова. In: Вестник НГИЭИ, Нижний Новгород: Нижегородский государственный инженерно-экономический институт, 2013, № 5, с. 38-49. / Dudoglo T. D., Onofrej A. Z. Ocenka demograficheskoj nestabil'nosti v Respublike Moldova. In: Vestnik NGIJeI, Nizhnij Novgorod: Nizhegorodskij gosudarstvennyj inzhenerno-jekonomicheskij institut, 2013, № 5, s. 38-49.

Кожухар В. Г. Українці Молдови: сторінки історії. In: Українці Молдови: Історія і сучасність. Кишинів: Елан, 2008, с. 19-45. / Kozhuhar V. G. Ukraïnci Moldovi: storinki istoriï. In: Ukraïnci Moldovi: Istorija i suchasnist'. Kishiniv: Elan, 2008, s. $19-45$.

Кожухарь В. Миграционные процессы в среде украинцев Молдовы. In: Patrimoniul etnologic: concepte, tendințe şi abordări. 23-24 mai 2017, Chișinău. Chișinău: „Notograf Prim” SRL, 2017, p. 63. / Kozhukhar'V. Migracionnye processy v srede ukraincev Moldovy. In: Patrimoniul etnologic: concepte, tendințe și abordări. 23-24 mai 2017, Chișinău. Chişinău: „Notograf Prim” SRL, 2017, p. 63.

Кожухарь В. Источниковая база исследования динамики движения украинского населения Республики Молдова в конце XX - начале XXI в. 
In: Patrimoniul cultural: cercetare, valorificare, promovare. Ediția 12. Vol. 1 adaos, 28-29 mai 2020a., Chișinău. Chișinău: Institutul Patrimoniului Cultural, 2020, p. 295-299. / Kozhukhar' V. Istochnikovaja baza issledovanija dinamiki dvizhenija ukrainskogo naselenija Respubliki Moldova v konce XX - nachale XXI v. In: Patrimoniul cultural: cercetare, valorificare, promovare. Ediția 12. Vol. 1 adaos, 28-29 mai 2020a, Chișinău. Chișinău: Institutul Patrimoniului Cultural, 2020, p. 295-299.

Кожухарь В. Историография динамики численности и миграции украинцев Молдовы в конце XX - начале XXI в. In: Tradiţii şi procese etnice. Chişinău: Institutul Patrimoniului Cultural, 2020b (Tipogr. „Grafema Libris”), p. 252-261. / Kozhukhar' V. Istoriografija dinamiki chislennosti i migracii ukraincev Moldovy v konce HH-nachale HHI v. In: Tradiţii şi procese etnice. Chişinău: Institutul Patrimoniului Cultural, 2020b (Tipogr. „Grafema Libris”), s. 252-261.

Макухин А. В. Современная миграционная ситуация в Республике Молдова и Приднестровье как череда «исходов» населения. In: PolitBook, № 1. Чебоксары: НИИ общественных и политических наук, 2015, с. 69-82. / Makuhin A. V. Sovremennaja migracionnaja situacija v Respublike Moldova i Pridnestrov'e kak chereda «ishodov» naselenija. In: PolitBook, № 1. Cheboksary: NII obshhestvennyh i politicheskih nauk, 2015, s. 69-82.

Медков В. М. Демография: Для студ. вузов. Ростов-на-Дону: Феникс, 2002. 448 с. / Medkov V. M. Demografija: Dlja stud. vuzov. Rostov-na-Donu: Feniks, 2002. 448 s.

Миграция в Молдове - краткая информация. In: Укрепление взаимосвязи миграции и развития в Молдове. Кишинев: CIVIS \& IASCI, 2010, с. 1117. / Migracija v Moldove - kratkaja informacija. In: Ukreplenie vzaimosvjazi migracii i razvitija v Moldove. Kishinev: CIVIS \& IASCI, 2010, s. 11-17.

Молдавские трудовые мигранты в Европейском Союзе: аспекты интеграции и проблемы возвращения. In: Морару В., Мошняга В., Руснак Г. Маятник миграции. Кишинэу: IIEŞP, 2012, с. 99159. / Moldavskie trudovye migranty v Evropejskom Sojuze: aspekty integracii i problemy vozvrashhenija. In: Moraru V., Moshnjaga V., Rusnak G. Majatnik migracii. Chişinău: IIEŞP, 2012, s. 99-159.

Мошняга В. Регулирование трудовой миграции в Республике Молдова: основные этапы и их специфика. In: Moldoscopie (Probleme de analiza politică), nr. 1 (XXXVI). Chişinău: USM, 2007, c. 33-48. / Moshnjaga V. Regulirovanie trudovoj migracii v Respublike Moldova: osnovnye jetapy i ih specifika. In: Moldoscopie (Probleme de analiza politica), nr.1 (XXXVI). Chisinau: USM, 2007, s. 33-48.
Мошняга В. Неурегулированная транзитная миграция из Республики Молдова: состояние и пути минимизации. In: Moldoscopie (Probleme de analiza politică), nr. 2 (XLI). Chișinău: CEP USM, 2008, c. 57-108. / Moshnjaga V. Neuregulirovannaja tranzitnaja migracija iz Respubliki Moldova: sostojanie i puti minimizacii. In: Moldoscopie (Probleme de analiza politica), nr. 2 (XLI). Chisinau: CEP USM, 2008, s. 57-108.

Мошняга В. Население Молдовы в контексте современных миграционных процессов. Молдова - Приднестровье. In: Работая вместе ради успешного будущего. Кишинэу: Издательский Дом, 2009, с. 156-172. / Moshnjaga V. Naselenie Moldovy v kontekste sovremennyh migracionnyh processov. Moldova - Pridnestrov'e. In: Rabotaja vmeste radi uspeshnogo budushhego. Kishinjeu: Izdatel'skij Dom, 2009, s. 156-172.

Надирова А., Корнелюк Н., Гагауз О. Сравнительный анализ демографической политики в Республиках Беларусь, Казахстан и Молдова. In: Аист на крыше. Демографический журнал. СПб.: Фонд гражданских проектов «Социумъ», 2017, № 4 (4), с. 24-31. / Nadirova A., Korneljuk N., Gagauz O. Sravnitel'nyj analiz demograficheskoj politiki V Respublikah Belarus', Kazahstan i Moldova. In: Aist na kryshe. Demograficheskij zhurnal. SPb.: Fond grazhdanskih proektov «Socium», 2017, № 4 (4), s. 24-31.

Палади Г, Бучучану-Врабие М. Молдова в процессе депопуляции. In: Основные вызовы демографической безопасности: сходства и различия в Молдове и Беларуси. Кишинев: Știința, 2010. http://www.demoscope.ru/weekly/2011/0455/analit01.php. (vizited 20.03.2020). / Paladi G, Buchuchanu-Vrabie M. Moldova v processe depopuljacii. In: Osnovnye vyzovy demograficheskoj bezopasnosti: shodstva i razlichija v Moldove i Belarusi. Kishinev: Shtiinca, 2010. http://www. demoscope.ru/weekly/2011/0455/analit01.php. (vizited 20.03.2020).

Перепись населения 2004 г. Демографические, национальные, языковые, культурные характеристики. Статистический сборник. Т. 1. Кишинев: Statistica, 2006. 492 с. / Perepis' naselenija 2004 g. Demograficheskie, nacional'nye, jazykovye, kul'turnye harakteristiki. Statisticheskij sbornik. T. 1. Kishinev: Statistica, 2006. 492 s.

Перепись населения и жилищ в Республике Молдова, 12-25 мая 2014 года. In: Национальное Бюро Статистики. Перепись населения и жилищ 2014 (gov.md), 2016 (vizited 20.03.2020). / Perepis' naselenija i zhilishh v Respublike Moldova, 12-25 maja 2014 goda. In: Национальное Бюро Статистики. Перепись населения и жи- 
лищ 2014 (gov.md), 2016 (vizited 20.03.2020).

Поалелунжь О. М. Молдова в потоке международной миграции. In: Основные вызовы демографической безопасности: сходства и различия в Молдове и Беларуси. Кишинев: Știința, 2010. http:// www.demoscope.ru/weekly/2011/0455/analit01.php. (vizited 20.03.2020). / Poalelunzh' O. M. Moldova $\mathrm{v}$ potoke mezhdunarodnoj migracii. In: Osnovnye vyzovy demograficheskoj bezopasnosti: shodstva i razlichija v Moldove i Belarusi. Kishinev: Shtiinca, 2010. http://www.demoscope.ru/weekly/2011/0455/ analit01.php. (vizited 20.03.2020).

Скворцова А. Ю. Русские Бессарабии: опыт жизни в диаспоре (1918-1940гг.). Кишинев: Pontos, 2002. 279 c. / Skvorcova A. Ju. Russkie Bessarabii: opyt zhizni v diaspore (1918-1940 gg.). Kishinev: Pontos, 2002. 279 s.

Степанов В. Украинцы Республики Молдова. Влияние этногосударственного законотворчества, госучреждений и ведомств, этнокультурной среды на сохранение и развитие идентичности. Очерки трансформационного периода (1989-2005 гг.). Кишинев, Business-Elita, 2007. 710 c. / Stepanov V. Ukraincy Respubliki Moldova. Vlijanie jetnogosudarstvennogo zakonotvorchestva, gosuchrezhdenij i vedomstv, jetnokul'turnoj sredy na sohranenie i razvitie identichnosti. Ocherki transformacionnogo perioda (1989-2005 gg.). Kishinev: Business-Elita, 2007. $710 \mathrm{~s}$.

Субботина И. А. Гагаузы динамика численности и изменения в расселении (вторая половина XX - начало XXI в.). In: Этнографическое обозрение. М., 2005, № 5, с. 115-133. / Subbotina I. A. Gagauzy dinamika chislennosti i izmenenija $\mathrm{v}$ rasselenii (vtoraja polovina $\mathrm{XX}$ - nachalo XXI v.). In: Jetnograficheskoe obozrenie. M., 2005, № 5, s. 115-133.

Суляк С. Г. Этносы и языки Молдавии по результатам переписи 2004 г. и данным ГП «Центр государственных информационных ресурсов „Registru”». In: Русин. Кишинэу, 2013, № 3 (33), c. 94-101. / Suljak S. G. Jetnosy i jazyki Moldavii po rezul'tatam perepisi 2004 g. i dannym GP «Centr gosudarstvennyh informacionnyh resursov „Registru”». In: Rusin. Kishinev, 2013, № 3 (33), s. 94-101.

Суружиу В. Как власти намерены решать проблему дискриминации нацменьшинств в Молдове? In: http://www.noi.md/ru/news_id/218249, 20.04.2017 (vizited 17.03.2020). / Suruzhiu Viktor. Kak vlasti namereny reshat' problemu diskriminacii nacmen'shinstv v Moldove? In: http://www.noi.md/ ru/news_id/218249, 20.04.2017 (vizited 17.03.2020).

Табак И. В. Русское население Молдавии. Численность, расселение, межэтнические связи.
Кишинев: Штиинца, 1990. 137 с. / Tabak I. V. Russkoe naselenie Moldavii. Chislennost', rasselenie, mezhjetnicheskie svjazi. Kishinev: Shtiinca, 1990. $137 \mathrm{~s}$.

Тишков В. А. О Всероссийской переписи населения 2010 года: разъяснения для ретроградов и националистов, и предупреждения для чиновников и политиков. In: Этнополитический мониторинг переписи населения. Под ред. В. В. Степанова. М.: ИЭА РАН, 2011, с. 15-31. / Tishkov V. А. О Vserossijskoj perepisi naselenija 2010 goda: raz'jasnenija dlja retrogradov i nacionalistov i preduprezhdenija dlja chinovnikov i politikov. In: Jetnopoliticheskij monitoring perepisi naselenija. Pod red. V. V. Stepanova. M.: IJeA RAN, 2011, s. 15-31.

Тульский М. Некоторые итоги переписи 2004 года в Молдавии. In: http://www.demoscope.ru/ weekly/2006/0249/analit08.php, 2006 (vizited 12.03.2020). / Tul'skij M. Nekotorye itogi perepisi 2004 goda v Moldavii. In: http://www.demoscope. ru/weekly/2006/0249/analit08.php, 2006 (vizited 12.03.2020).

Фоменко В. Г., Кривенко А. В. Демографическая ситуация в Приднестровье в 1990-2000 годах. In: Демоскоп Weekly, 2002, nr. 73-74. http://tirastel. $\mathrm{md} / \sim \mathrm{tdsu} /$ region/osn_publ.shtm (vizited 12.03.2020). / Fomenko V. G., Krivenko A. V. Demograficheskaja situacija v Pridnestrov'e v 1990-2000 godah. In: Demoskop Weekly, 2002, nr. 73-74. http://tirastel. $\mathrm{md} /$ tdsu/region/osn_publ.shtm (vizited 12.03.2020).

Фоменко В. Г. Демографическая ситуация в Приднестровье в постконфликтный период. In: Материалы международной научно-практической конференции «Молдова-Приднестровье: общими усилиями - к успешному будущему. Социальные аспекты». Кишинев: $\mathrm{Cu}$ drag, 2009, с. 81101. / Fomenko V. G. Demograficheskaja situacija v Pridnestrov'e v postkonfliktnyj period. In: Materialy mezhdunarodnoj nauchno-prakticheskoj konferencii «Moldova-Pridnestrov'e: obshhimi usilijami - k uspeshnomu budushhemu. Social'nye aspekty». Kishinev: Cu drag, 2009, s. 81-101.

Victor Cojuhari (Chișinău, Republica Moldova). Doctor în istorie, Institutuil Patrimoniul Cultural.

Виктор Кожухарь (Кишинев, Республика Молдова). Доктор истории, конференциар, Центр этнологии, Институт культурного наследия.

Victor Kozhukhar (Kisinau, Republic of Moldova). $\mathrm{PhD}$ in History, Associate Professor, Institute of Cultural Heritage.

E-mail: vcojuhari60@gmail.com

ORCID: https:// orcid.org/0000-0002-6313-049X 